\title{
Post-Keynesian theory, direct action and political involvement
}

\author{
G.C. Harcourt*
}

In this paper I analyse how I became an economist and at the same time a democratic socialist and a Christian. I also explain how I became politically involved after my graduate studies at Cambridge in the late I9sos and started lecturing at Adelaide. When back in Cambridge in the Ig6os, teaching this time, the war in Vietnam persuaded me to support direct action through the anti-war movement in South Australia when I returned to Adelaide in 1967. The Ig6os and the events of the time did influence my approach to teaching and research. More concretely, I was persuaded that ideology and analysis were indissolubly mixed and that one's stance should always be made explicit. How these influenced what I did in my years in Adelaide, and then from 1982 back in Cambridge, along with my earlier experiences, are all described in the paper.

JEL classifications: $A 0, A I, A 2, B o, B 2, B_{3}$

Keywords: political economy, political and religious beliefs, ideology and analysis, direct action

\section{Introduction}

The aim of the paper is to analyse how my decision to become an economist intertwined with my search as an undergraduate for a political philosophy and religious belief. By the end of my undergraduate course at Melbourne University in I953 I had become both a democratic socialist and a Christian, the latter decision taking much longer to reach than the former

* Jesus College, Cambridge, UK, and School of Economics, University of New South Wales, Australia. I am grateful to Philip Arestis and Prue Kerr for comments on a draft of the paper.

Correspondence Address:

G.C. Harcourt, The Australian School of Business, The University of New South Wales, NSW, Sydney NSW 2052, Australia, e-mail: gch@unsw.edu.au.

Received I5 July 20IO, accepted 20 November 2010

C) INTERVENTION 8 (I), 2OII, II7-I28 
due to my social and religious origins. Once I had finished graduate studies at Cambridge in the late I950s and started lecturing at Adelaide, I also became politically involved in a number of areas but always through the susual channelss. It was not until I was teaching in Cambridge in the 1960s and becoming more and more upset by Australia's involvement in the Vietnam War that I decided when I returned to Adelaide in 1967 to support direct action through the anti-war movement in South Australia. This decision also much influenced my approach to teaching and research as, greatly influenced by the writings of Chomsky, Dobb and Stretton, I became convinced that ideology and analysis were indissolubly mixed and that your own stance must always be made explicit. How this influenced what I did in my years in Adelaide from then on, and then in Cambridge from 1982 on, is described in the later parts of the paper.

\section{Early years}

To provide the background to my topic, I set out some autobiographical facts. I was born in Melbourne in June 1931, one of twin boys. (My brother became a most distinguished and respected academic dentist which would have pleased Keynes.) My parents were middle class; my father was a leather merchant, my mother before marriage, Head Mistress of the infant school of a posh Melbourne girls' school. They were right wing, agnostic, assimilationist Jews. In the r930s Melbourne was a stuffy, snobby, sectarian city with great hostility between the Roman Catholic and Protestant communities who, nevertheless, happily formed a united front when ganging up on the Jews. There was (is) a considerable Jewish population in Melbourne. It was (is) split between pro- and anti-Zionist factions, left-wing and right-wing political beliefs and orthodox and liberal religious views. In recent years, the split takes in support for, as opposed to (distressed) opposition to, Israel's behaviour towards the Palestinians.

We were educated at private schools (where people went to school was very important in Melbourne social values) and experienced first hand what I would call sthoughtless British Anti-Semitism r which served to scar my childhood. As part of my parents' assimilationist stance we were entered as $\mathrm{C}$ of $\mathrm{E}$ (Church of England) at our primary and secondary schools (one of which was $\mathrm{C}$ of $\mathrm{E}$, the other, Methodist) so we went to the whole of morning assemblies including prayers, and to chapel and divinity classes. (Most Jewish boys - they were boys only schools - did not.) I absorbed uncritically both my parents' agnosticism about religion and their very right-wing political views allied with simplistic patriotism taking in the British Empire and all it allegedly stood for. I did early on have a burning dislike of injustice and intolerance, especially concerning some of my relatives' attitudes to Australia's indigenous people.

Though I now do not agree with my parents' stance, I cannot criticise them for it - they were doing what they considered best in the very unsettled and worrying situations of the I930s and I940s. My mother tried hard to be a good parent but she was insecure and possessive. Whereas my father understood well the two roles of parents: supportive and protective when children are young, supportive but letting go when children are grown up. 
He was an especially fine man; he exhibited all the ancient verities and he was much respected and loved by many, many people. My parents were devoted to one another and a good team. For various reasons my mother was, as I noted, a rather insecure person and it was only after she had a severe stroke in 1972 that she realised that people did care for and about her.

Though I always wanted to be a vet (and took three years to get the natural science prerequisites at university entrance examinations to allow me to do so), I had also done economics as a ffill in subject for four years at school and liked it. So when I went to Melbourne University in I950, I decided to do a B.Com degree and become an economics schoolteacher. (This allowed me to have a generous scholarship while at university in return for several years teaching in the state system afterwards.)

I had always been in the shadow of my very bright twin brother, John. We had been moved up ahead of our age as a result of his high marks - a disaster for both of us socially and for me intellectually. But when I went to university I came into my own, as it were, and topped the first year of the B.Com degree, not least because of the encouragement and tutoring of my first mentor, Joe Isaac (who, after a distinguished academic career, was the first economist to serve on the then Australian central wage-fixing institution, the Commonwealth Arbitration Commission). Joe persuaded me to leave the Victorian secondary education department, which paid my scholarship and to try to become a university teacher.

As a result of the subjects I took in my first year, especially Economic Geography I (really comparative economic systems), I soon became a democratic socialist in my politics. I found out that societies organised their economic and social affairs mostly in an irrational and unjust manner, especially with regard to the use of essential resources that would be needed by future as well as by present generations. Making up my mind about belief in God (the two pressing issues for thoughtful students in those days were stances on politics and belief or not in God) took much longer because of a perceived gap between the actual behaviour and professed beliefs of Christian groups. (I knew little about Jewish ones but my father, having been orthodox until his early twenties, then decided that all religion was bunkum and religious people, hypocrites!)

I spent my university years at Melbourne after 1950 in Queen's College, a Methodist institution, which had a theological school where would-be Methodist ministers were trained. Many of them became firm friends with whom I discussed the nature of religious belief. The upshot was that in my fourth year as an undergraduate I made a Popperian-type decision: Suppose that there is a God (all three, with the Christian community a natural step on, or perhaps a takeover of, its Jewish forebears), and see how we go from there. That is to say, would subsequent experiences falsify the hypothesis? (They have not yet.) I had no trouble reconciling the precepts of Christianity with democratic socialist principles. So I coupled my Christian beliefs with them. I argued that the only difference between Humanists, who also wanted to create just and equitable societies, and believers, who wished to do the same, was that the Humanists thought they could do it unaided, whereas the Christians thought that the Holy Spirit would help them to work in mostly secular institutions to attain these ends: first, by taking on the dead weight of personal failings which so drag people down - think of poor Wittgenstein - and, secondly, by emphasising the nature and importance 
of the community - the people of God - rather than of the individual. So I was baptised in Queen's College chapel in 1953 and joined the Australian Labour Party (ALP) soon after. And when I took up my first teaching post in Adelaide in 1958, I began to call myself the only Jewish Methodist in that fair city.

\section{Economics education}

The economics course I did at Melbourne was very Cambridge (England) orientated but it also took in Hicks and Kalecki as well as Samuelson, Schumpeter and Chamberlin. I also studied the classical economists and Marx in a third year history of economic thought (HET) course. Obviously Keynes was a major influence - I encountered the great man in my first year when intending Honours students read and went to lectures on A Tract on Monetary Reform (I923) (and Philip Wicksteed's Common Sense of Political Economy (I9IO), still two of my favourite books). We were lectured on the themes of The General Theory in the second year by Donald Cochrane (of Cochrane and Orcutt fame) and Joe Isaac. I had read The General Theory over the preceding long vacation but, needless to say, I found it extremely hard going, not least because I tried to read it in bed! In later years we were introduced to Michal Kalecki's writings on income distribution by Joe Isaac, to Maurice Dobb's writings on the transition from Feudalism to Capitalism and to his classic Political Economy and Capitalism (I937 and 1940). (When I subsequently took an Honours Class at Adelaide on Radical Economics in the I970s, I told the students that they should read Dobb's book and Milton Friedman's Capitalism and Freedom (1962) before they could make an informed choice on where they stood politically and on their approach to economic analysis).

The most influential article I read as an undergraduate was Kurt Rothschild's Price theory and oligopoly (1947). It has influenced my thinking ever since. He argues that oligopolists are as interested in secure as in maximum profits and that Clausewitz's principles of war are the appropriate framework with which to analyse oligopolistic behaviour. In my fourth year honours dissertation I tried to introduce Rothschild's oligopolists as the principal decisionmakers in the economy into the model of The General Theory, to see if this affected the analysis of the systemic behaviour of capitalism. These themes run through much of my work ever since.

Philip Arestis once asked: Why this approach and not some other? I suppose historical reasons dominated - it was the early I950s and in Australian universities, the economics of British universities and especially of Cambridge dominated both syllabuses and to some extent the background of the staff. The General Theory had been published in 1936 and Keynes had only died four years before. Tom Asimakopulos, who was my contemporary as a Ph.D student at King's, Cambridge in the I950s, had a not dissimilar training at McGill before coming to Cambridge. When he was asked by Philip Arestis and Malcolm Sawyer to write an autobiographical essay for the first edition of their splendid volume, A Biographical Dictionary of Dissenting Economists (Arestis/Sawyer 1992), he refused because he did not view his approach to economics as a dissenting one, but rather as firmly placed within the 
then mainstream developments of economic theory especially associated with Marshall and Keynes. His mentor, Jack Weldon, had taught him within this framework (after a thorough grounding in the writings of the classical political economists). Perhaps Paul Samuelson's Foundations (1947) figured more prominently in his training than in mine, but otherwise we had a very similar background. In his later years, from the mid i96os on, our views became even closer as he adopted more and more the approaches of Joan Robinson and Kalecki, so that he became post-Keynesian in his approach.

In my case, Marx was also very important though, as I have written before, I never really understood him until I had in the I970s and I980s three wonderful scholars of Marx as my Ph.D students - Prue Kerr, Allen Oakley and Claudio Sardoni. Of course, with hindsight, I can now see more clearly how all these influences and others - the classicals, Sraffa, Kaldor, Dobb - come together in my approach and in my evaluation of the approaches of other economists.

\section{A research student at Cambridge in the mid I95os}

In 1955 I went to King's College, Cambridge to do a Ph.D, first, with Nicky Kaldor (a disaster) and then with Ronald Henderson as supervisors, and, as I wrote, I was appointed to my first lectureship at Adelaide in early 1958. Initially the topic of my Ph.D dissertation was the implications for the theory of the firm and of the trade cycle of secure profits being as important as maximum profits for oligopolists. In the event it was on the systemic implications of the use of historical cost accounting procedures for setting prices and measuring income for dividend and taxation purposes in a period of inflation, not completely unrelated!

While a research student I also made a special study of Joan Robinson's The Accumulation of Capital (1956) - this was the start of our friendship - and I subsequently lectured on the book to the Honours students in Adelaide. (It did, of course, greatly influence from then on the approach I took to teaching and research.) I also started teaching the first year Keynesian course at Adelaide in the early I960s when Peter Karmel (who had designed the course) left his chair at Adelaide to become the first Vice Chancellor of the Flinders University of South Australia. The lectures were the basis of my first book, Economic Activity (1967), co-authored with Peter Karmel and Bob Wallace. Bob took the course over from me when I returned to Cambridge in 1963, first, for a year's study leave and then, completely unexpectedly, to a University Lectureship in the Cambridge Faculty of Economics and Politics and a Fellowship at Trinity Hall, posts to which I was appointed while on leave. As a result I held the appointments for three years, having obtained three years leave without pay from Adelaide to do so, as I felt I had a moral obligation to return to Adelaide.

When Robin Matthews was elected to the Drummond Chair of Political Economy at Oxford in 1965 , I took over his first year macroeconomics course at Cambridge. I lectured from the notes that became Economic Activity. I told the undergraduates present at the lectures that 30 years or so previously Keynes had lectured to a specially chosen set of undergraduates from the proof sheets of The General Theory. I added that they were not that special and I was 
not Keynes, but that the lectures were on the economics of Keynes. The most distinguished of the undergraduates present was Mervyn King, now Governor of the Bank of England. Three times in public (sort of) he has singled out the lectures for special praise; I wish he would put this in writing!

\section{Political activities}

During my first six years at Adelaide I was politically active in a number of areas but always through the susual channels . I was Secretary (in later years Vice-President and President) of the Howard League for Penal Reform, S.A. Branch, and President of the Mitcham Branch of the Australian Labor Party (ALP) (we met in our home so you can imagine what a large membership the branch had). I also was associated with the bi-partisan movement then formed to try to rid Australia of the White Australia Policy in our immigration laws. As the ALP had, for historical reasons, White Australia in its platform, I could not be officially associated as I (and many other members of the ALP with the same views) would have been expelled from the Party, so we worked behind the scenes to get White Australia removed from the platform and Australia's immigration policy.

I published quite regularly in my first years as a university lecturer once my Ph.D was out of the way (I had also published three articles before I was awarded it in late I959, one of which probably secured my appointment at Adelaide). I wrote my papers in the third person with numbered paragraphs as though they were natural scientific reports. There was no intrusion of personality or values in them. Moreover, I was very chuffed when after one of my introduction to Keynesian macroeconomics lectures at Adelaide, I overheard a student saying: "I can't work out whether Harcourt is Labor or Liberal [Tory in Australia] from his lectures!«

\section{Teaching at Cambridge in the I96os}

All this was to change during my years as a teacher at Cambridge. First, I allowed a little of my personality to intrude into my papers (have a look at the opening paragraph of > The accountant in a Golden Age`, Oxford Economic Papers, 1965). I had a great burst of publication over that period, mostly in what we now call `Brownie Point $`$ journals, and there was even something approaching wit in my narratives. This last was subsequently to grow, so much so that Joe Stiglitz, in the first draft of his unfavourable review article in the Journal of Political Economy (1974) of my 1972 book on capital theory, commented that some of my jokes (in the book) were "nearly as funny as Harcourt seems to think they are ", a remark he removed from the published version, rather to my disappointment. Joe sent me the first draft of his review article and I, perhaps foolishly, sent him eight pages of comments on it. I have kept a file on this episode as I received comments on Joe's draft from Joan Robinson, Eric Russell, Mario Nuti, Neil Laing, and Piero Sraffa. Joan's comment began: »I am sorry you have let this ass get under your skin«. I should add that Joe had a room next to me in Cambridge 
in the mid I96os when Samuelson and Solow sent him to the sother Cambridger to hear its views first hand. Sadly, Joan and Joe did not get on at all - principally Joan's fault, not Joe's - but Joe and Nicky Kaldor did. Joe and I also became friends then and have remained so. (Indeed he recently told our son, Tim, when he met him in Australia, that I had been a great influence on him. He did not say whether it was good or bad.) In my view, he has been doing God's work in recent years with his courageous, outspoken and forth right views on economics and politics (he was always a progressive in his politics).

Secondly, and more to the point, I began to be very disturbed about the Vietnam war and Australia's role in it, using conscripts, and as one of the few respectable allies of the USA in that most immoral of wars. The Faculty at Cambridge was divided into doves and hawks, as were Bob Solow (a hawk) and Ken Arrow (a dove). Both visited Cambridge in 1963-64. To his credit, Solow subsequently changed his mind. Knowing I was to return to Australia in 1967, I had myself briefed by Martin Bernall and Ajit Singh who were really extremely well informed on Vietnam, for I was determined to do something about Australia's involvement when I returned in early 1967.

\section{Direct action in the 1960s and 1970 s}

I became a foundation member of the committee of the Campaign for Peace in Vietnam in South Australia (CPV), which was formed in mid 1967 and subsequently its chair for two periods later on. As well as writing pamphlets, organising meetings, writing letters to newspapers and going on the radio and TV, we also organised protest marches and moratorium marches. At first, anyway, we took a non-violent stance (until one of our marches was attacked by drunken soldiers; the police were none too gentle either). On the whole we cooperated with the police but in 1970 there was a major confrontation associated with a sit down in the middle of the city as the culmination of a moratorium march. Many arrests were made. I have to say that although I was prominent all day as a marshal of the march and after, I was not arrested, partly because the cops needed some of the leaders out of jail to negotiate the release of those in jail, partly because as a moderate in the anti-war movement, I had good personal relationships with the police. I regard confrontation with them as counter-productive (our quarrel was not with them). Also my wife Joan and our children had received many death threats as well as one actual attempt to kill us by trying to blow up our car, so that the police were not unsympathetic to us as people. (Adelaide was in many ways a very small town; the ASIO man [the Australian equivalent of the UK's Mis] who spied on me was the son-in-law of one of my colleagues in the Economics Department!) For five and a half years I averaged two and a half days a week in the anti-war movement and also took part in action at the university to reform aspects of its governance. (I should add that I gave my fair share of lectures, looked after graduate students, wrote papers, including the survey of capital theory in the June I969 Journal of Economic Literature, Harcourt (1969), and books and took a full part in the department's activities, as well as playing cricket in the summer and Australian Rules Football in the winter, running three miles every day, and being the father of four young children.) 
My conversion to the need for direct action if other more orthodox means proved ineffective, and if the issues concerned were fundamental enough, was greatly helped by reading Noam Chomsky's essay, The responsibility of intellectuals (1967) and Hugh Stretton's remarkable book, The Political Sciences (1969). Chomsky argued that it was not good enough, say, for natural scientists to invent napalm, but not take a stance on the use made of it - they had a social responsibility to speak up. Stretton argued that in the social sciences (and other disciplines) there was no such thing as an objective, value-free discipline, that ideology and analysis were indissolubly mixed. To claim otherwise was to corrupt both yourself and your students. Personal values always should be made explicit in teaching, speaking and writing. (Maurice Dobb made similar arguments.)

So in my classes from then on, I started every course of lectures by setting out my philosophical, religious and political values, and how they were entwined with my approach to political economy. I said I did not expect my students necessarily to agree with me but I wanted them to know exactly where I was coming from. I followed the same course in public addresses, speaking on radio and TV and writing political pamphlets, articles, letters to the editor; and so on. All my papers and books from then on were permeated with these views. I was especially outspoken in the 1960 s and I970s as I was inspired and humbled by the example and courage of the student radicals involved in the anti-war movement and university reforms. After all, I was by then a tenured professor whereas they were using their first time at university to fight for just causes, often at the expense of the time they could give to their studies which in turn often affected the marks they received - a much higher permanent sacrifice than someone in my position could ever have been asked to make.

From then on, I have always tried to call a spade a spade in what I say and write, taking Kalecki's 1943 classic, Political aspects offull employment, as the role model. I try to use dispassionate arguments in my political writings and speeches, also sto hate the sin but love the sinner`, and I never expected ‘favoured nation ‘ treatment if I broke the law on protests - only that I should be neither framed nor beaten up in the process! (For the record, I was not.)

\section{Return to Cambridge in 1982}

When I returned to Cambridge in 1982 I still held to these values but I have never been as politically active again. Partly this was because though I had been an important $>$ back room boy ‘ for the ALP in policy formation in the I970s, the ideologues in the British Labour Party did not (and still do not) want to know. (For example, I was the economist on the ALP's National Committee of Inquiry, which was set up in the late I970s to see why the party had done so badly in the 1975 and 1978 federal elections. I wrote the first draft of discussion paper number six on economic policy and the future of Australia. In it I set out a package deal of policies, which was post-Keynesian in approach. It was especially influenced by Ralph Willis's lone voice advocacy in the ALP and the writings of Eric Russell and Wilfred Salter on incomes policy from the I950s on. I like to think that Bob Hawke set this policy in motion for a good half hour after he was elected Prime Minister in I983.) 
Partly also, my academic workloads - teaching, research, supervising graduate students, college, faculty and university administration - were much higher and I had set myself the task of documenting the intellectual history of what may be called Joan Robinson and her circle - to see what was lasting in the contributions of the first generation and after of Keynes's pupils. As I returned to Australia permanently at the end of July 20 oro (Joan [Harcourt] and I flew home on our $55^{\text {th }}$ Wedding Anniversary), I have all but fulfilled the task with the publication in 2006 of The Structure of Post-Keynesian Economics: The Core Contributions of the Pioneers and the publication in 2009 with Prue Kerr of the intellectual biography, Joan Robinson. I still have to see through my last major project, a two-volume handbook on post-Keynesian Economics for Oxford University Press, USA, which I am co-editing with Peter Kriesler; and I am preparing two more volumes of selected essays to be published by Palgrave Macmillan on Skidelsky's Keynes and Other Essays and The Making of a Post-Keynesian Economist: Cambridge Harvest. In Australia I am to mentor indigenous students doing undergraduate and graduate courses at the University of New South Wales (UNSW), so I shall still be politically active in my $80^{\text {th }}$ year and on.

\section{Egotistical evaluation}

As Prue Kerr had already suggested, Philip Arestis also asked that I add a section summarising my own work, emphasising my main contributions to economics and indicating the extent to which democratic socialist principles and Christianity have influenced them. I respond with reluctance because >blowing your own trumpet` is not an Australian characteristic (even if it is a Cambridge one). The greatest compliment I was ever paid was by Anand Chandavarkar, an Indian friend of mine in the World Bank. He said (I paraphrase): "I always think of you as the Keith Miller of economics, the last of the great all-rounders. « As Miller, the great Australian all-round test cricketer of the I940s - I960s, was my boyhood hero, it is easy to understand why I was so chuffed by his comment. And it is true that I have written articles and books on theory, policy, applied work [including one econometric paper(!)], intellectual biography, history of the economic theory and even methodology. Partly this is because my generation thought this was what economists did; partly because I was never a narrow specialist but followed up whatever caught my eye and/or what I thought were important and pressing issues.

In a most generous preface to a selection of my essays published in 1995, the late Mark Perlman classified my writings into four groups:

a. Works analysing contemporary economic theoretical problems

b. Works synthesizing states of debates in economic theory

c. Works having a distinctly biographical flavour and pertaining to various contemporary economists, and

d. Works pertaining to economic and allied social policies. 
He singled out as my "greatest research contributions [...] the essays written under the second rubric «, judging me to be a »something of a master« because I get »each side's position sstraight and sympathetically stated [and my] judgements are original, pithy and sound" (Perlman 1995: ix, emphasis in original). He wrote that I had »become of that rare breed, a teacher's teacher [, one] of only a few who really can teach others what and how to teach" (Perlman 1995: ix). He quoted with approval what I had come to believe what economics is about', that it is

"to make the world a better place for ordinary men and women, to produce a more just and equitable society. In order to do that, you have to understand how particular societies work and where the pockets of power are, and how you can either alter those or work within them and produce desirable results for ordinary people, not just for the people who have power. I see economics as very much a moral as well as a social science and very much a handmaiden to progressive thought. It is really the study of the processes whereby surpluses are created in economies, how they are extracted, who gets them and what they do with them. All economies have created surpluses in one way or another. Capitalism does it in a particular way and that is the process in which I am most interested because I live in capitalist economies. At the same time I would like to help to create a society where the surplus is extracted and used in a way quite different from a capitalist society." (Perlman 1995: vii)

I believe my commitment to democratic socialism and Christianity run through, and are integral to, this statement. Over the years I have had to lower my sights as to what we may hope to achieve in an increasingly imperfect world. The most explicit statements of this are to be found in the paper, The mixed economy, written with Prue Kerr and published in 1980; in my 1982 John Curtin Memorial Lecture, Making Socialism in your own country; and in the 1992 Second Donald Horne Address, Markets, madness and a middle way.

\section{Io. Concluding remarks}

Finally, may I quote what Ken Arrow (who has been a friend since we met in Cambridge in 1963, who I regard as the greatest living economist and who I admire tremendously as a compassionate human being) wrote in the Foreword to volume three of my Festschrift, edited by Claudio Sardoni and Peter Kriesler (1999):

"I only came to realise later the extent to which [his] concerns were motivated by strong humanitarian and egalitarian values which derive from [his] religion. Regardless of their source, these are the values which both sides in the rg6os controversies [on capital theory] hold high and which have come under steady attack in the last twenty years. Geoff's firm convictions have been a pillar of fire in the night." (Arrow 1999: xviii)

I close by saying how grateful Joan and I are to the organisers of the conference at Bilbao and the speakers at two of the sessions for honouring me and my work. When I am depressed 
about the state of the world - climate change, the Middle East, the rise of budget-size fetishism, for example - I take heart that there are progressive humane people out there doing God's work (even if they are agnostics or atheists) and I feel privileged to be able to join them, not least the concentration of such people at the conference in Bilbao.

\section{References}

Arestis, P., Sawyer, M. (eds.) (1992): A Biographical Dictionary of Dissenting Economists, Aldershot: Edward Elgar.

Arrow, K.J. (1999): Foreword, in: Sardoni, C., Kriesler, P. (eds.), Keynes, Post-Keynesianism and Political Economy. Essays in Honour of Geoff Harcourt. Volume Three, London and New York: Routledge, xvii-xviii.

Chomsky, N. (1967): The responsibility of intellectuals, in: Roszack, T. (ed.), The Dissenting Academy, New York: Pantheon Books, 254-98.

Dobb, M.H. (1937, 1940): Political Economy and Capitalism, London: Routledge \& Kegan Paul.

Friedman, M. (1962): Capitalism and Freedom, Chicago: Chicago University Press.

Harcourt, G.C. (1965): The accountant in a Golden Age, in: Oxford Economic Papers, 17, 66-80.

Harcourt, G.C. (1969): Some Cambridge controversies in the theory of capital, in: Journal of Economic Literature, 7, 369-405.

Harcourt, G.C. (1972): Some Cambridge Controversies in the Theory of Capital, Cambridge: Cambridge University Press.

Harcourt, G.C. (1995): Capitalism, Socialism and Post-Keynesianism. Selected Essays of G.C. Harcourt, Aldershot, UK, Brookfield, US: Edward Elgar.

Harcourt, G.C. (2006): The Structure of Post-Keynesian Economics: The Core Contributions of the Pioneers, Cambridge: Cambridge University Press.

Harcourt, G.C. (1982): Making socialism in your own country, presented at the 1982 John Curtin Memorial Lecture, August 1982, reprinted in: Sardoni, C. (ed.) (1992), On Political Economists and Modern Political Economy. Selected Essays of G.C. Harcourt, London: Routledge, 28I-96.

Harcourt, G.C. (1992): Markets, madness and a middle way, The Second Annual Donald Horne Address, Melbourne, in: Australian Quarterly, 64, 1992, I-17.

Harcourt, G.C., Karmel, P.H., Wallace, R.H. (1967): Economic Activity, Cambridge: Cambridge University Press.

Harcourt, G.C., Kerr, P. (1980): The mixed economy, in: North, J., Weller, P. (eds.), Labor, Sydney: Ian Novak, I84-95.

Harcourt, G.C., Kerr, P. (2009): Joan Robinson, Basingstoke: Palgrave Macmillan.

Kalecki, M. (1943): Political aspects of full employment, in: Political Quarterly, I4, 347-56.

Keynes, J.M. (1923): A Tract on Monetary Reform, The Collected Writings of John Maynard Keynes, Vol. IV, London: Macmillan, I97I.

North, J., Weller, P. (eds.) (1980): Labor, Sydney: Ian Novak.

Perlman, M. (1995): Preface, in: Harcourt, G.C., Capitalism, Socialism and Post-Keynesianism. Selected Essays of G.C. Harcourt, Aldershot, UK, Brookfield, US: Edward Elgar, vii-x. 
Robinson, J. (1956): The Accumulation of Capital, London: Macmillan.

Roszack, T. (ed.) (1967): The Dissenting Academy, New York: Pantheon Books.

Rothschild, K.W. (1947): Price theory and oligopoly, in: Economic Journal, 57, 299-320.

Samuelson, P.A. (1947): Foundations of Economic Analysis, Cambridge/Mass.: Harvard University Press.

Sardoni, C. (ed.) (1992): On Political Economists and Modern Political Economy. Selected Essays of G.C. Harcourt, London: Routledge.

Sardoni, C., Kriesler, P. (eds.) (1999): Keynes, Post-Keynesianism and Political Economy. Essays in Honour of Geoff Harcourt. Volume Three, London and New York: Routledge.

Stretton, H. (1969): The Political Sciences. General Principles of Selection in Social Science and History, London: Routledge.

Stiglitz, J.E. (1974): The Cambridge-Cambridge controversy in the theory of capital; a view from New Haven: a review article, in: Journal of Political Economy, 82, 893-903.

Wicksteed, P.H. (1980): The Common Sense of Political Economy, London: George Routledge and Sons Ltd. 